
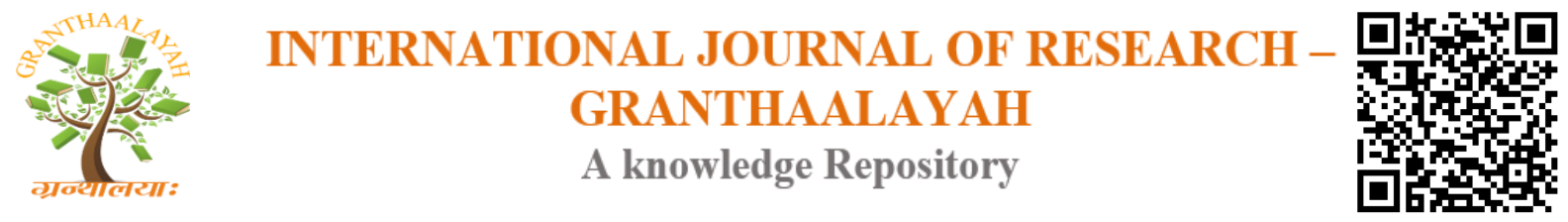

Social

\title{
FACTORS THAT AFFECT OUR SPIRITUAL WORLD IN MODERN TIMES AND THEIR SOCIAL AND PHILOSOPHICAL ANALYSIS
}

\author{
N.A.Abdullayeva ${ }^{* 1}$ \\ ${ }^{* 1}$ Department of Public Disciplines, Azerbaijan State Oil and Industrial University, Baku, \\ Azerbaijan
}

\begin{abstract}
Today, there is a great need for the revision of the system of spiritual values that constitute the cultural basis of every society from the public practice and high intellect to which humanity has acquired, and re-evaluating their role in human life. Thus, the globalization process in the world raises the problem of spiritual values and creates the need for scientific-philosophical analysis of social-spiritual aspects of free society building.

It should be noted that the spiritual world of the Azerbaijani people, which has repeatedly encountered the trials of the history with an interesting and rich history in the crossroads of different religions and cultures, has emerged, formed and developed on a rich foundation, grown into its national-psychological trajectory. It is very important to study the universality inherent in the national-cultural and spiritual systems, cultures for the philosophical view of Azerbaijan in modern times.
\end{abstract}

Keywords: Spiritual Values; Moral Values; Culture; Globalization.

Cite This Article: N.A.Abdullayeva. (2017). "FACTORS THAT AFFECT OUR SPIRITUAL WORLD IN MODERN TIMES AND THEIR SOCIAL AND PHILOSOPHICAL ANALYSIS." International Journal of Research - Granthaalayah, 5(7), 422-428. https://doi.org/10.29121/granthaalayah.v5.i7.2017.2149.

\section{Introduction}

All the great peoples of the world, along with their material wealth, continue their existence with their spiritual riches. It is impossible for the societies deprived from this wealth to continue their existence. The future of a people who is far from its national culture and who forsakesits moral values are in serious doubt. Because the individual or society without historical consciousness is doomed to perishin the whirl of various cultures and civilizations.

Spiritual values are the cultural basis of every society. In their absence, the internal balance of society is violated, and there is a danger of its melting in a culture that is strong in the world. 
The article focuses on our centuries-old national and spiritual values in modern times that have been impacted by various influences and the determination of the future development of our spiritual culture.

On the one hand, the ongoing influence of the Islamic values to which our people are historically related and on the other hand the admiration to Western culture that is widely spread in the society necessitate choosing a more successful path to ensure the futher development of our spiritual culture.

It should be noted that after restoration of its independence, Azerbaijan gained the opportunity to develop national culture and morality and to use the progressive values of Islam in this work effectively. Addressing the role of our religious values in the development of our spiritual values, Heydar Aliyev stated in his speech delivered at the 1998 International Conference on Modernity and Religious Spiritual Values, held in Baku: "Effective use of religious and spiritual values in the modern world is important to every nation, every religion" [1-9].

\section{Materials and Methods}

It is of great importance today to research and study religion associated with namely spiritual values. It helps us to understand the content and essence of our national-spiritual values in the modern era, to understand and perceive which heirs of cultural heritage we are.

It is very important today to explore the Islamic religion, which is an integral part of the spiritual world of our people, to study its place and role in the system of spiritual values and its influence to our national mentality.

This is one of the most discussed topics on the agenda. It has many historical and social-political reasons. One of them is the isolation of our people from the religion, that has been practiced for centuries, in the open and secret way during the Soviet era. Today's religious recurrence, religious predilection observed in society is the reaction of the people in new condition against the past religious discrimination.

It is no accident that, many people who do not have religious faith today, often trying to observe the religous rules, demonstrate themselves as believers, faithful ones. In fact, religion exists as a custom, tradition, way of life for them and religions continues its existence in this way in our modern life. Of course, the opinion of the people with no true faith, belief in the development of our culture, the role of Islam in formation of our national and spiritual values is ambiguous. Many of them doubt about the positive role of Islam and ambigously assess its impact on our spiritual culture.

One of the outstanding issues assessed ambigously in the society is the intensive influence of the western values on our country, on the development of our national-spiritual values, in the light of the globalization policy that Western states are trying to implement in the world today. Globalization, which is the main direction of world politics, is accompanied by the intense influence of Western culture in all countries of the world, including Azerbaijan. The strong influence of the globalization policy, which prevents the preservation of the national-spiritual 
culture of the peoples of the world, their originality, resulting these cultures to melt in the Western culture, on ourspiritual culture, which has been eroded by our people for centuries and developed by passing from generation to new generation, its future development, is an inevitable fact. Without a doubt, this effect can not be judged unambiguously. This process is of multivector, versatile.

It should be noted that the globalization process covers all aspects of human life - social, economic, cultural, spiritual, political, legal, etc. ones. Different opinions are expressed by the specialists from various fields - sociologists, philosophers, political scientists, culturologists and others on the global view of the world and the theory of globalization. For example, S. Arzneshtadt analyzes the history of ancient and contemporary civilizations' cultural dialogue, saying that contemporary civilizations exist as a multitude of national, human symbols and traditions that have been polished by numerous mutual choices. Globalization does not exclude multicolourism, diversity and variability, but rather necessitate them, because the future fate of human culture depends on it [10].

S.Hantiqton states that "civilizations do not go to one another, do not enrich each other, on the contrary, they are always in conflict, trying to weaken or destroy each other. Another civilian, who claims to approach the West, should either give up its values or deny this wish" [9].

Generally speaking, the globalization process in the world poses a problem of spiritual values and creates the need for scientifically-philosophical analysis of social-spiritual aspects of free society building. As a result of opening the Western culture to the world, both inside of this culture and in the societies remaining under the blows of its spreading waves, it has created "values shock" and also created a conflict between universality and locality.

The contradictions expressed by this conflict coversuch problems as modernity and tradition, humanity and nationalism, and so on in morality. As a result, both the struggle for values and their dialogue in humanity are manifested. It is very important for the philosophical idea of the Azerbaijani philosophy, that explores such conflicts, to study national-cultural and spiritual systems and universality inherent in cultures.

In general, there is a great need arisen to review the religion, ethics and other spiritual values from the public practice and high intellectual level mankind has achieved and reassess their role in people's lives.

It is known that after restoration of our independence, as in other areas, there has also been a gap in the spiritual life of our people. In such a situation, besides applying to our past heritage, there has also been a need for new spiritual values inherent in the essence of the newly established society.

When it comes to the spiritual values of the past, it is mentioned about the traditions of our people that preceded the Soviet-era traditions. However, our nation has lived through the Soviet era and has gained rich spiritual achievements during this period. Our spiritual achievements during the Soviet era are also reflected in our morality today. But the basis of the spiritual world of the Azerbaijani people is undoubtedly the spiritual values of the pre-Soviet era. 
We would like to point out that, when talk about spiritual values today, the moral values are generally considered. True that, our moral values are an integral part of our spiritual values, but as we know,the spiritual values are a broader concept. This concept includes a system of values that constitutes the basis of the spiritual life of society.

Value is an event of culture. It's both social and personalby its essence. Its essence includes the general definition of the wealth of the material and spiritual world, revealing their positive and negative sides for the human and society. Value is related to the definitions of importance, benefit, or damage. In other words, "values" are valuable, meaningful ideas and opinions.

When it comes to the spiritual values of the people, it is primarily understood its language, religion, science, literature, art, philosophy, traditions, morality, and generally spiritual culture. Spiritual culture is the process of creating and utilizing the spiritual wealth of society. It should be regarded as a dialectical process consisting entirely of spiritual creativity. Spiritual culture includes science, philosophy, literature, art, religion, morality, politics, law, etc. intellectual and spiritual development of society which are the results of human spiritual activity.

Many scholars justify the concept of culture primarily in the sphere of spiritual life, seeking it in the spiritual world of people. It is natural, because the existence of every nation is inseparably linked to its spiritual culture. In culture, it is envisaged to cover all aspects of human activity, the results obtained and the total amount of wealth created. It's a very complicated social event.

Culture is the sum total of both material and spiritual wealth accumulated historically by humanity, as well as the creation of these riches, and their use for them, as well as ways of transmitting to future generations. The development of culture is possible by adopting the best examples of national and spiritual heritage.

Spiritual values, their development dialectics are closely linked to public relations, as well as to the nature of the social structure, and take a special place in the structure of human development. The characteristics of each social structure, the way people think and behave themselves are reflected in the general system of spiritual values. Therefore, when analyzing their content, it is necessary to approach the issue with public relations in the unbreakable connection.

Here it is impossible to forget about the inheritance, because national-spiritual values play a crucial role in shaping the people and the nation, and the identity. The national-spiritual values of each nation are shaped historically and form the basis of the national existence of that nation.

Thus, spiritual values create logical relationships between different generations, periods of historical development, provide the indivisibility, integrity and thus its strong educational significance. Spiritual values combine the complex values that are within the scope of certain rules and norms, which are useful for the satisfaction of the spiritual needs of the individual as the fruit of the intellectual activity of a person, serving his intellectual growth and moral perfection. These values cover all aspects of human life, activity, and become a specific criterion of moral and spiritual qualities. 
Today, the interdependence between people is largely dependent on the intellectual level of the society and the maturity degree of spiritual relations between them. In this sense, the intensive, comprehensive and harmonious development and acquisition of spiritual values, such as the acquisition of scientific knowledge, progressive political ideas and attitudes, a totality of high moral and aesthetic perceptions, senses and emotions, is the basis of healthy moral development and social competence of society, people and concrete individual. The people who protect, upgrade, and adhere to their spiritual values are always welcomed with great sympathy.

It should be noted that, after restoration of Azerbaijan's independence, Azerbaijan has been closely cooperating with the peoples of foreign countries, in the socio-economic, cultural and spiritual spheres. In this condition, our people embrace progressive universal spiritual values and enrich themselves. This is also very natural. Because it is impossible to have a Chinese barrier between peoples and their cultures. Peoples learn and benefit from each other and enrich their own cultures at the expense of each other. However, every nation also strives to maintain its national-spiritual values, traditions. Because they are important features that distinguish the people from other peoples and ensure their national identity. The commitment of peoples to their historical roots, national and spiritual values is a great factor.

We would like to note that at the end of the 20th and early 21 st century, Azerbaijan was characterized by ethnic-national Turkish thinking, ideology, and its religious aspect closely related to Islamic morality. That is, during this period, our mentality was shaped by the synthesis of Turkism and Islamism. But other factors also affect this process. It is necessary to emphasize here the factor of Russia and the West. Almost in the twentieth century, the Russian factor played a bigger role. The influence of the Russian factor on our spiritual values has both positive and negative aspects. Negative effect is anti-national, anti-Turkish policy, imposed by empire policy, and its positive effect is the acquaintance with universal values, Western civilization. At the same time, in the Soviet era, it is necessary to emphasize the anti-Islam, generally the atheist policy.

It is known that during the Soviet period there were contradictory opinions about the essence of the Holy Koran of Islam, the spiritual and moral norms and principles. But today, Koran being translated into our mother tongue, the main roots of this book are directly studied from itself, allowing us to become acquainted with the rich spiritual values of Islam. Islam is a religion that promotes love, conscience, patience, hardship, spiritual purity, helping in to instill human qualities for those who need love for parents, respect for older people, respect for women, mercy to children, caring for children, etc, assisting us to enrich our morality.Islam forbids people killing, stealing, lying, witnessing falsely, immorality, condemning evil, also propagandizes goodwill, compassion and love to people, propagation and warning. The people, that do not adhere to the religion of Islam, also adhere to these moral values. If one of them treats these moral values as moral principles of Islam, others regard these principles as universal moral values. We do not intend to criticize one or the other. Because we are interested in spiritual values that are important to the society as a whole.

Recall that the religion of Islam was largely criticized by its rules of veil-cover habits, polygamy and all the problems of the woman, the closed way of life, isolation from life, and the reasons for her conversion to the slave were mainly associated with hijab. In the history of humanity and 
religion, women have been regarded as a symbol of obedience, moral cleanness, purity, honor, and dignity. Today, according to the attitude of the Azerbaijani woman to Islam, she can have "hijab". This is her right. However, it should be noted that in the 21 st century "cover" is not a symbol of spiritual cleanness of a woman; Today, women are equally a citizen of society together with men.

\section{Results and Discussions}

In the modern era, it is not right to evaluate the impact of the West on the development of our spiritual values. On the one hand, penetrate such Western ideas and values asnew achievements in science and technology, democracy, pluralism, freedom of speech and press, human rights protection, new economic relations, etc. into our country have a positive impact on the development of our spiritual culture in modern times; On the other hand, the spiritual and moral values of the West widespread in our country through the Internet, television channels, foreign films and literature deteriorating the taste of people and especially youth and teenagers, as well as their spirituality, had a negative impact on the development of our national-spiritual culture.

In general, the subject of cultural heritage and modernization has always been on the agenda of our spiritual life since the early part of the 19th century and includes various elements of influence.

The outstanding personalities, thinkers and writers of Azerbaijan- A.A.Bakikhanov, M.Sh.Vazeh, S.A.Shirvani, H.B.Zardabi and M.F.Akhundov have highly appreciated the Western culture and its development level in the XIX century and considered it a criterion for the progress of our national culture. This trend continued and strengthened in the early twentieth century. Azerbaijani romantics - M.Hadi, A.Sahhat, H.Javid, A.Huseynzadeh and others have promoted the Western culture in their works and urged the people to use the achievements of this culture. However, they also appreciated the Western culture and its achievements, as well as advised to approach it with a selection and use it prudently.

\section{Conclusions \& Recommendations}

As a result of the socio-philosophical analysis of this problem, which is the subject of research, we must note that modern culture without national culture can not exist, and national culture can not exist without modern development. In our view, it is possible to achieve national cultural progress through a reconciling position between these two views, that is, achieving synthesis and reconciliation between national and spiritual values and Western culture and values.

\section{References}

[1] Abasov, A. Socio-cultural problems of the modern era. Baku: Sada, 2006, 374p.

[2] Aslanova, R. Globalization and cultural diversity. Baku: Science, 2004, 264p.

[3] Women in Azerbaijan (history and modernity, end of XIX century - beginning of XX century). Baku: "Azerbaijan" publishing house, 2006, 272 p.

[4] Haydar Aliyev. Our religion is the spiritual wealth of our people. Baku, 1999, $165 \mathrm{p}$.

[5] Aliyev, R.Y. Islamic and Azerbaijani culture. Baku: Publishing house "Abilov, Zeynalov andtheir sons", 1998, 117 p. 
[6] Ramiz Mehdiyev. Azerbaijan during the globalization: development strategy. "Azerbaijan" newspaper, May 26, 2004.

[7] History of the Azerbaijani philosophy, t.1 - Baku, Elm, 2002, 360 p.

[8] Malysheva, D. Post-Soviet Vostok in the search for Religious Identity. M., 2002, 127 pp.

[9] Hantigton,C. Stillation of civilization. M., AST, 2005, 357p.

[10] Social Change and Modernity. Berkeley. University of California Press. 1992, 462 p.

\section{Information About The Author}

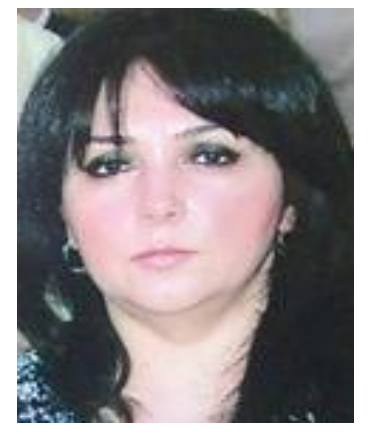

Associate Professor of the Department of "Social Sciences" of the Azerbaijan State Oil and Industry University, PhD in philosophy Ms. Naila Amir Abdullayeva.

Number of scientific publications: 21.

Field of Interest: History of Philosophy, Theoretical Problems of Philosophy, Social Philosophy.

*Corresponding author.

E-mail address: zumruda@ inbox.ru 